\title{
Ultrastructural localization of chromogranin: a potential marker for the electron microscopical recognition of endocrine cell secretory granules
}

\author{
IAN M. VARNDELL ${ }^{1}$, RICARDO V. LLOYD ${ }^{2}$, \\ BARRY S. WILSON ${ }^{2}$ and JULIA M. POLAK ${ }^{1}$ \\ ${ }^{1}$ Department of Histochemistry, Royal Postgraduate Medical School, Hammersmith Hospital, \\ Du Cane Road, London W12 OHS, UK \\ ${ }^{2}$ Department of Pathology, University of Michigan Medical School, Ann Arbor, Michigan 48109, \\ USA
}

Received 17 January 1985 and in revised form 9 May 1985

\begin{abstract}
Summary
Using a monoclonal antibody (LK2H10) directed against human chromogranin, we have been able to localize this soluble glycoprotein to the matrix of secretory granules from a wide variety of endocrine cells. In the gut, enterochromaffin, enteroglucagon, glucose-dependent insulinotropic peptide, gastrin, and neurotensin-containing cells exhibit chromogranin immunoreactivity. In our system, chromograninimmunoreactive material was restricted to the halo of human pancreatic glucagon-containing secretory granules within A-cells. Chromogranin immunoreactivity was also localized to secretory granules in phaeochromocytomas, gastrinomas, medullary carcinomas of the thyroid and a carotid body tumour (chemodectoma). Chromogranin is proposed as a potential marker for the ultrastructural recognition of endocrine cell secretory granules.
\end{abstract}

\section{Introduction}

The molecular composition of catecholamine-containing secretory (chromaffin) granules of the adrenal medulla has been analysed in considerable detail (Winkler, 1976; Phillips \& Apps, 1979; Winkler \& Westhead, 1980; Winkler \& Carmichael, 1982). Three major glycoproteins, the tetrameric catecholamine converting enzyme dopamine- $\beta$ hydroxylase, glycoproteins (GP) II and III have been identified as components of the secretory granule membrane (Cahill \& Morris, 1979; Huber et al., 1979; Abbs \& Phillips, 1980). Structurally identical forms of dopamine- $\beta$-hydroxylase and GP III have also been isolated from the soluble fraction of the chromaffin granules (Fischer-Colbrie $e$ t al., 1982), 
together with a group of highly acidic glycoproteins collectively referred to as chromogranins. Quantitatively, the major form of the secretory granule matrix soluble glycoproteins is chromogranin A which is chemically similar, if not identical, to secretory protein I of the parathyroid gland granules (Cohn et al., 1982, 1984).

Chromogranin A, which comprises about $40 \%$ of the soluble proteins in chromaffin granules (Winkler, 1976), contains approximately $5.4 \%$ carbohydrate, predominantly oglycosidically linked trisaccharides (Kiang et al., 1982). The precise amino acid sequence of chromogranin A remains enigmatic (Winkler \& Carmichael, 1982), presumably because the purified molecule seems to be unstable (Kirshner, 1974). Consequently, the published molecular weight for chromogranin A varies between 68000 (human; O'Connor et al., 1984) and 74000 to 81200 (bovine; Smith \& Winkler, 1967; Kirshner \& Kirshner, 1969; Helle, 1971). Recently, the chromogranins have been characterized immunologically (Falkensammer et al., 1985).

Using a monoclonal antibody (LK2H10) which recognizes one epitope of chromogranin, Lloyd \& Wilson (1983) were able to demonstrate the efficacy of this system for the immunocytochemical recognition of endocrine tissue. In a subsequent publication and using the same LK2H10 antibody, Wilson \& Lloyd (1984) detected chromogranin immunoreactivity in 126 normal and neoplastic endocrine tissues (with demonstrable secretory granules) but not in 113 cases of nonendocrine normal and neoplastic tissue or in 46 endocrine tissues or tumours without demonstrable secretory granules. Recently, our group conducted a systematic immunohistochemical investigation of the distribution of chromogranin in the human gastrointestinal tract (Facer et al., 1985). We were able to demonstrate that chromogranin immunoreactivity, identified using antibody LK2H10, was a reliable marker for gut endocrine cells at the light microscope level, although some inconsistency in the degree of immunostaining was noted over the range of processing regimes adopted.

In the present study, we have attempted to demonstrate the ultrastructural localization of a human chromogranin epitope in a wide range of normal and neoplastic endocrine cells using a monoclonal antibody.

\section{Materials and methods}

Human tissue samples were obtained from surgery within $30 \mathrm{~min}$ of resection (see Table 1). The tissue was chilled on wet ice before fixation in cold $2.5 \%$ glutaraldehyde ( $25 \%$ ultrapure; EMScope Laboratories, Ashford, Kent, UK) in $0.1 \mathrm{M}$ sodium phosphate buffer, $\mathrm{pH} 7.2$, for $2 \mathrm{~h}$. Following fixation and rinsing in phosphate buffer containing $0.1 \mathrm{M}$ sucrose, half of each sample was osmicated ( $1 \%$ osmium tetroxide in phosphate buffer for $1 \mathrm{~h}$ ). All blocks were then rinsed and processed through ethanols into Araldite epoxy resin.

Ultrathin sections (silver to silver-grey) were cut and mounted onto cleaned, uncoated 300-mesh nickel grids.

Antibody LK2H1O

Antibody LK2H10 was raised as described in detail by Wilson \& Lloyd (1984). Briefly, a BALB/c mouse 
Chromogranin immunoelectron microscopy

Table 1. Human tissues studied.

\begin{tabular}{ll}
\hline Tissue & Number of cases \\
\hline Gastrointestinal tract & \\
Stomach & \\
$\quad$ Antral mucosa & 6 \\
$\quad$ Fundic mucosa & 6 \\
Duodenum & 6 \\
Jejunum & 4 \\
Ileum & 6 \\
Colon & 6 \\
Rectum & 5 \\
Pancreas & \\
Neonatal & 4 \\
Pre-adult & 4 \\
Adult & 8 \\
Adrenal & \\
Normal medulla & 3 \\
Tumours & \\
Gastrinomas (1 primary; 2 metastases) & 3 \\
Phaeochromocytomas & 5 \\
Medullary carcinomas of thyroid & 3 \\
Chemodectoma & 1 \\
Insulinomas & 5 \\
Glucagonomas (all pancreatic) & 4 \\
\hline
\end{tabular}

was immunized with a minced human phaeochromocytoma-Freund's adjuvant emulsion (five bi-weekly intraperitoneal injections). Spleen cells were separated and fused with NS-I mouse myeloma cells (Galfre et al., 1977). Culture supernatant fluid from growing clones was then screened for antibody activity against cryostat sections of the original tumour. Hybridoma LK2H10 was selected and sub-cloned by limiting dilution over mouse spleen feeder cells. The characteristics of the antibody were determined by adsorption against purified human chromogranins and chromogranin $\mathrm{A}$, by immunoelectroblot staining and by avidin-biotin-peroxidase immunohistochemistry. An extensive evaluation of antibody LK2H1O specificity is given in Wilson \& Lloyd (1984).

\section{Immunostaining}

The immunogold staining procedure (Varndell et al., 1982; Varndell \& Polak, 1983; Polak \& Varndell, 1984) was employed using a primary antibody dilution at $I: 100$ to $1: 200$ for $I \mathrm{~h}$ at room temperature with minimal etching ( $2 \% \mathrm{w} / \mathrm{v}$ hydrogen peroxide for $2 \mathrm{~min}$ ). Antigen-antibody complex sites were visualized using a goat anti-mouse IgG antibody adsorbed onto 10 or $20 \mathrm{~nm}$ colloidal gold (Janssen Pharmaceutica, Beerse, Belgium) at dilutions of $1: 30$ and 1:10 respectively. The sections were then counterstained with uranyl acetate and lead citrate and viewed by transmission electron microscopy at $80-100 \mathrm{kV}$. 


\section{Assessment of immunostaining}

The distribution of colloidal gold in different cellular compartments was quantified by counting the number of particles per unit area according to the formula:

$$
\mathrm{r}=\left(\frac{\sum \mathrm{x}}{\mathrm{a}} / \frac{\sum \mathrm{x}^{\prime}}{\mathrm{a}^{\prime}}\right)
$$

where $\mathrm{x}$ is the number of gold particles associated with particular organelles per cell (e.g. secretory granules, in whole or part); $a$, the area of the immunostained organelles counted per cell; $x^{\prime}$, the number of gold particles per cell not associated with particular organelles ('background'); and a', the area of cell containing $x^{\prime}$ but excluding $x$ (a should equal or approach $\mathrm{a}^{\prime}$ ). The 'nonspecific' staining was considered to be negligible if:

$$
r \geqslant 12
$$

\section{Controls}

Procedures for the establishment of method specificity were carried out (Van Leeuwen, 1982; Varndell \& Polak, 1984) at optimal primary antibody titre (1:100-1:200). Serum specificity was ascertained by preadsorbing the anti-chromogranin serum with electrophoretically purified (dopamine- $\beta$-hydroxylasefree) human chromogranin A (a generous gift from Dr D. T. O'Connor, Veteran's Administration Hospital, San Diego, USA; see O'Connor et al., 1984, and Wilson \& Lloyd, 1984, for details of the purification procedure). The chromogranin antibody was also preadsorbed with dopamine- $\beta$-hydroxylase (bovine adrenal medulla $\mathrm{D} \beta \mathrm{H}$; Sigma, UK) at concentrations up to $2 \times 10^{-7} \mathrm{M}$ diluted antibody.

\section{Results}

A wide range of endocrine cell types in the gastrointestinal tract were found to exhibit chromogranin immunoreactivity. Enterochromaffin (EC) cells were particularly densely immunostained (Fig. 1). Enteroglucagon (EG), glucose-dependent insulinotropic peptide (GIP), gastrin (IG) and neurotensin (N) storing cells were also found to contain chromogranin immunoreactive material. In all cases, chromogranin immunoreactivity was restricted to the secretory granule matrix. Immunocytochemically-identified somatostatin-containing endocrine cells in both gut and pancreas were apparently nonimmunoreactive to the chromogranin antibody ( $\mathrm{LK} 2 \mathrm{H} 1 \mathrm{O}$ ) when applied at the electron microscope level to tissue processed as described in this study (Fig. 2).

In the human pancreas, only one endocrine cell type was found to exhibit chromogranin immunoreactivity, the glucagon-containing (A) cell (Fig. 3). In the alpha granules of A cells, the chromogranin immunoreactivity was localized only to the moderately electron-dense halo (Fig. 4). Chromogranin immunoreactivity was also localized to secretory granules of normal adrenal medulla, phaeochromocytomas (Fig. 5), a carotid body tumour, gastrinomas (Fig. 6) and medullary carcinomas of the thyroid. Using monoclonal antibody $\mathrm{LK} 2 \mathrm{H} 10$ in this electron microscopical immunocytochemical study, we were unable to detect chromogranin immunoreactivity in secretory vesicles of neural origin.

The immunoreactivity of the chromogranin antibody was completely abolished by incubation with $1 \mathrm{nmol}$ purified chromogranin $\mathrm{A} / \mathrm{ml}$ at optimal antibody titre (Fig. 7). 


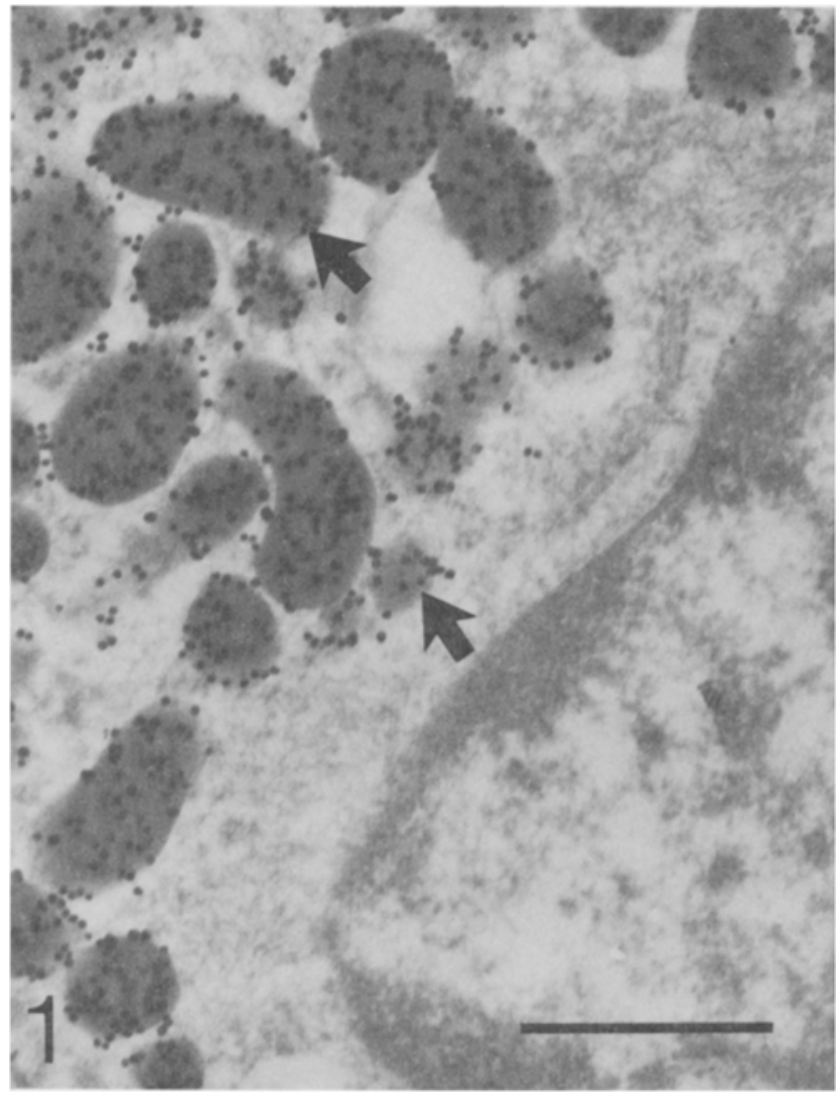

Fig. 1. Electron micrograph of enterochromaffin cell from human colon immunostained with monoclonal antibody LK2H10. Immunoreactive sites were localized with a $20 \mathrm{~nm}$ colloidal gold immunoreagent. All the electron-dense pleomorphic secretory granules (arrows) were found to exhibit chromogranin immunoreactivity. Scale bar, $0.4 \mu \mathrm{m}$.

Preadsorption with dopamine- $\beta$-hydroxylase had no effect on chromogranin immunostaining.

\section{Discussion}

A large number of human endocrine cell secretory granule types have been shown to exhibit chromogranin immunoreactivity. The localization of this protein to the intragranular matrix is in keeping with the preliminary findings of Aunis et.al. (1980) in bovine adrenal medulla, and Wilson \& Lloyd (1984) and O'Connor et al. (1983a,b, 1984) in human tissues, and offers some support to the contention, based on biochemical evidence presented by Sen et al. (1979), that one rôle for chromogranin (specifically chromogranin $A$ ) is to stabilize the stored components. 


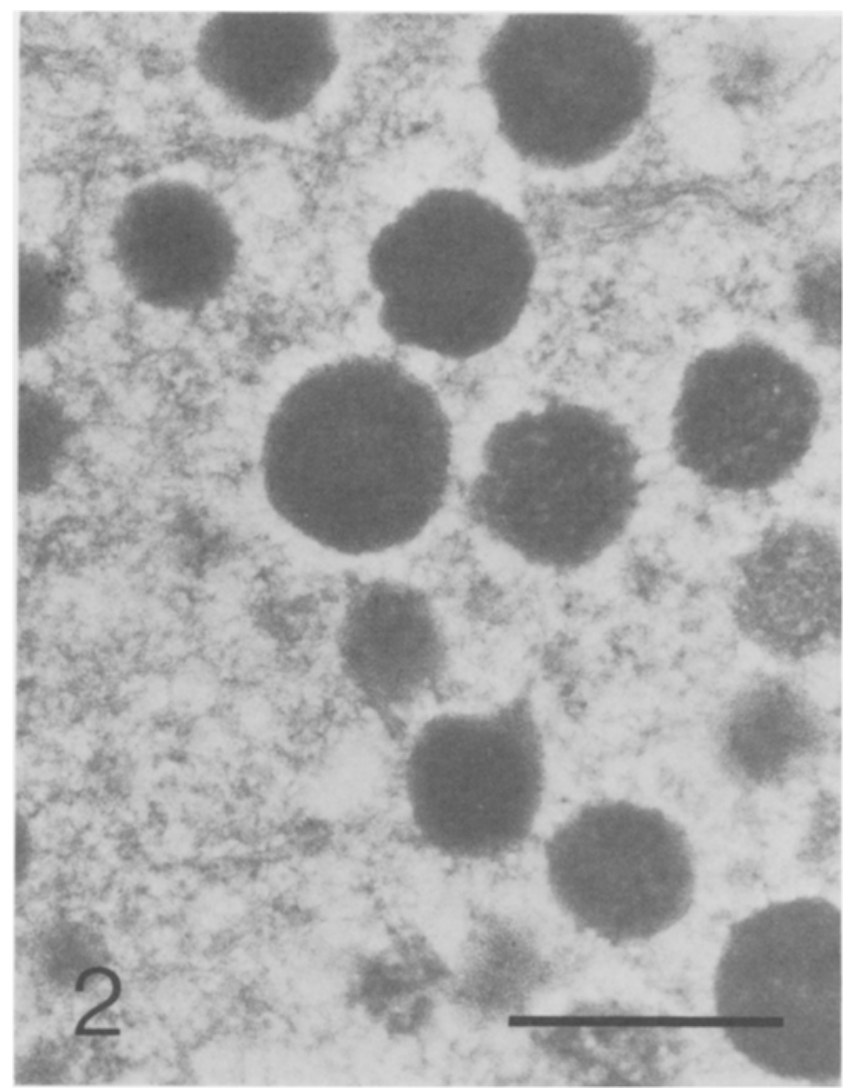

Fig. 2. Electron micrograph of somatostatin-containing cell from human gastrointestinal mucosa. The preparation has been immunostained with monoclonal chromogranin antibody. No immunoreactivity is observed. Scale bar, $0.5 \mu \mathrm{m}$.

Fig. 3. (a) Electron micrograph of neonatal human pancreatic islet immunostained with a chromogranin monoclonal antibody. All four endocrine cell types are visible (B, insulin- $[\beta]$; $D$, somatostatin; PP, pancreatic polypeptide-containing cells). The glucagon-containing (A) cell exhibits chromogranin immunoreactivity (arrowed). Immunogold staining procedure with $20 \mathrm{~nm}$ gold particles. Scale bar, $2 \mu \mathrm{m}$. (b) Electron micrograph of adult human pancreatic islet showing adjacent insulin- (B) and glucagon- (A) containing cells. Chromogranin immunoreactivity ( $I 0$ nm gold particles) is localized to the A cell secretory granules (arrowed). Note in this preparation, the grid-mounted sections were incubated by immersion in all immunoreagents, thus no topographic segregation of chromogranin is evident. Scale bar, $0.5 \mu \mathrm{m}$.

Fig. 4. High magnification electron micrograph of a single glucagon-containing secretory granule immunostained to reveal chromogranin immunoreactive sites. The immunoreactivity is clearly restricted to the moderately electron dense halo (large arrows). The small arrows indicate the morphological transition zone between core and halo. This preparation was immunostained by floating the grid on all immunoreagents; because there is no penetration of immunoglobulins into the section only the antigenic sites exposed on one surface are labelled. Scale bar, $0.1 \mu \mathrm{m}$. 

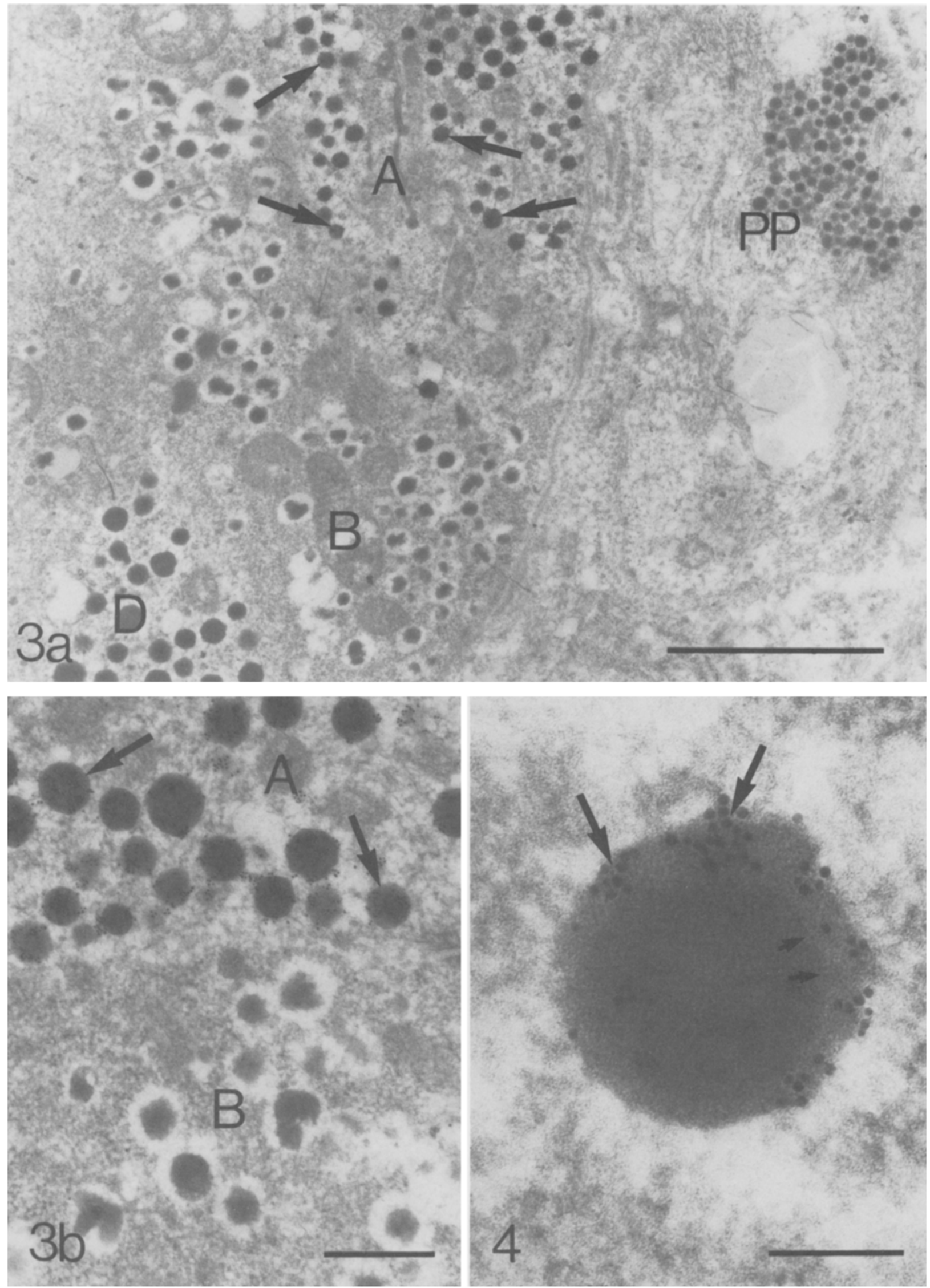

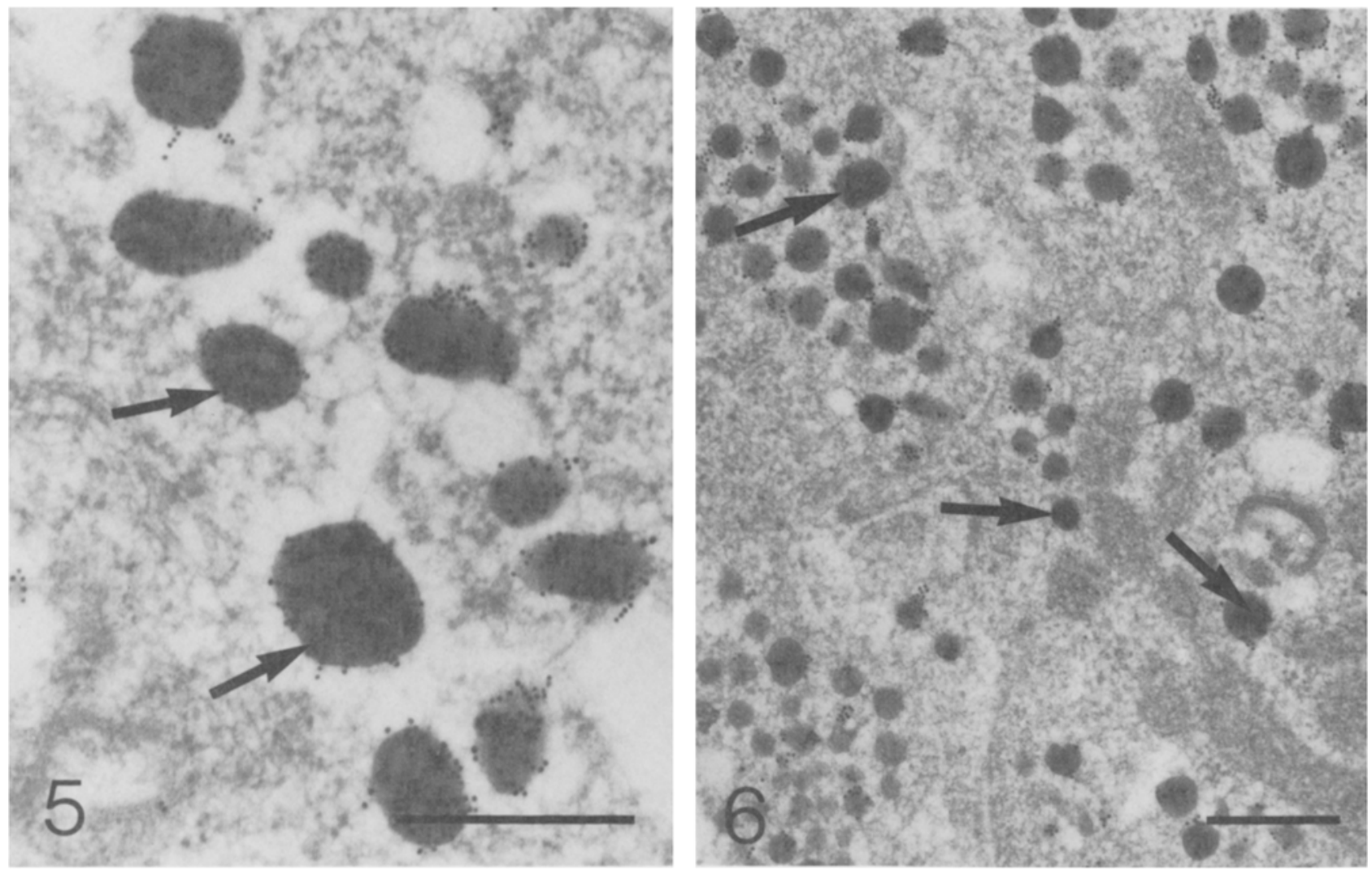

Fig. 5. Electron micrograph of secretory granules from human phaeochromocytoma intensely immunostained to reveal sites of chromogranin immunoreactivity ( $10 \mathrm{~nm}$ colloidal gold; arrowed). Scale bar, $0.5 \mu \mathrm{m}$.

Fig. 6. Electron micrograph of gastrin-producing cells from the liver metastasis of a human pancreatic tumour immunostained with chromogranin monoclonal antibody $\mathrm{LK} 2 \mathrm{H} 10$. Immunoreactive sites are restricted to the electron-dense secretory granules (arrowed). Immunogold staining procedure with $10 \mathrm{~nm}$ colloidal gold particles. Scale bar, $0.5 \mu \mathrm{m}$.

Not all endocrine cells of the human gut exhibited chromogranin immunoreactivity (e.g. somatostatin-containing cells) using the combination of monoclonal antibody LK2H10 and the preparative procedures for transmission electron microscopy described here. It should be emphasized, however, that glutaraldehyde was used as the fixative of choice throughout this study. Van Ewijk et al. (1984) evaluated the effect of different fixatives on monoclonal antibody binding efficiency and stressed that different antigenic determinants may react variably to different fixation protocols. This point could be reinterpreted to include the same antigenic epitope in different subcellular compartments. If, as seems likely, chromogranin conveys structural stability on a range of secretory proteins within intragranular matrices, it is reasonable to consider that the different 


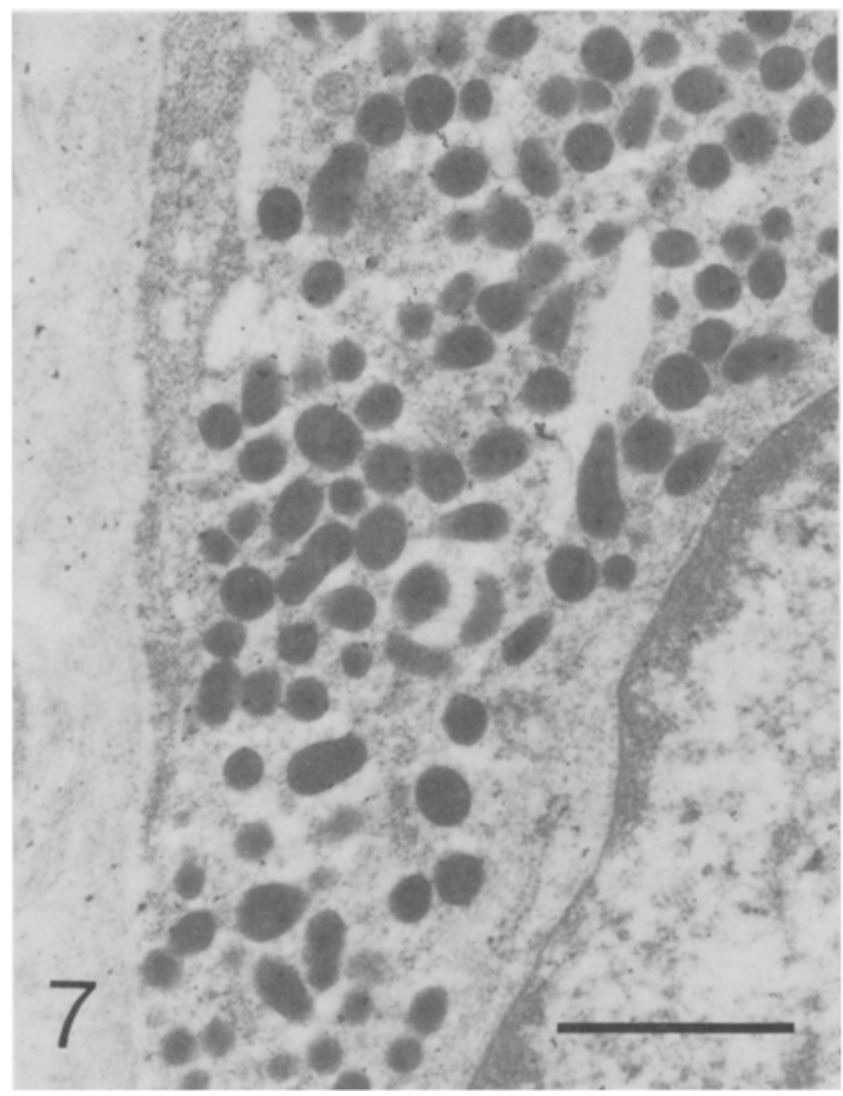

Fig. 7. Electron micrograph of enterochromaffin cell from human colonic mucosa. The preparation has been immunostained using monoclonal antibody LK2H10 preadsorbed with 1 nmol purified human chromogranin A per ml diluted antibody. The secretory granules are not immunolabelled (cf. Fig. 1). Scale bar, $1 \mu \mathrm{m}$.

chromogranin-secretory product complexes thus formed may react in different ways to even a single fixative. Consequently, it is necessary to consider that preparative procedures, particularly fixation, are exceedingly important if the preservation of chromogranin-immunoreactive epitopes at the ultrastructural level is to be achieved.

This 'preparation-dependent' immunolocalization is further highlighted by the highly specific alpha cell halo localization of chromogranin immunoreactivity. In their original paper, Lloyd \& Wilson (1983) mentioned that glucagon-producing cells exhibited the greatest immunoreactivity to antiserum LK2H10 whereas insulin-producing cells showed the least. This finding was subsequently corroborated (Facer et al:, 1985). In contrast, O'Connor et al. (1983a,b) used polyclonal antisera and recorded chromogranin A to co-exist with insulin in human and bovine pancreatic beta cells. Recently, Cohn et al. (1984) detected the secretory protein I-chromogranin A family in somatostatin- and pancreatic polypeptide-containing, but not in insulin- or glucagon-containing cells of 
rat pancreatic islets. All four human pancreatic endocrine cell types have been immunostained using monoclonal antibody LK2H10 on freeze-dried tissue vapour-fixed with benzoquinone (Facer et al., 1985). Clearly the conditions under which this antibody in particular and monoclonal antibodies in general are used must be carefully defined (see Mason et al., 1983; Van Ewijk et al., 1984).

Whilst the differential effect of tissue preparation on the particular chromogranin epitope recognized by monoclonal antibody LK2H10 prejudices its use as a universal endocrine cell marker antibody at the electron microscopical level under routine preparative conditions, we can justifiably propose that chromogranin is the endocrine secretory granule immunodeterminant most reliably localized at the electron microscope level. Previously, an argentaffin (Hamperl, 1927; Portela-Gomes \& Grimelius, 1982) or argyrophil (Grimelius, 1968; Grimelius \& Wilander, 1984) silver impregnation cytochemical technique was necessary. It is likely that the increasing application of cryogenic techniques for transmission electron microscopy (Tokuyasu, 1984; Dudek et al., 1984) will reduce the possibility of solvent-induced structural change which may be responsible for the loss of chromogranin antigenicity, and which is particularly encountered when monoclonal antibodies are utilized.

It is interesting to note also that chromogranin immunostaining may be of use to electron microscopists in the differential recognition of endocrine secretory granules from other subcellular organelles (e.g. primary lysosomes or exocrine storage vesicles). This is particularly relevant in cases of cytoplasmic degranulation (either natural or induced by poor fixation) which is frequently encountered in neuroendocrine neoplasms.

In conclusion, the absolute distribution of chromogranins $\mathrm{A}$ and $\mathrm{B}$ (Falkensammer et al., 1985) within endocrine tissues will only be attained with a mixture of monoclonal antibodies recognizing different epitopes. The results obtained thus far are highly encouraging in that chromogranin immunostaining has potential as an endocrine cell marker at the ultrastructural level.

\section{References}

ABBS, M. T. \& PHILLIPS, J. H. (1980) Organization of the proteins of the chromaffin granule membrane. Biochim. biophys. Acta 595, 200-21.

AUNIS, D., HESKETH, J. E. \& DeVIlliers, G. (1980) Immunohistochemical and immunocytochemical localization of myosin, chromogranin $A$ and dopamine- $\beta$-hydroxylase in nerve cells in culture and in adrenal glands. J. Neurocytol. 9, 255-74.

CAHILL, A. L. \& MORRIS, S. J. (1979) Soluble and membrane lectin-binding glycoproteins of the chromaffin granule. J. Neurochem. 32, 855-67.

COHN, D. V., ZANGERLE, R., FISCHER-COLBRIE, R., CHU, L. L. H., ELTING, J. J., HAMILTON, J. W. \& WINK LER, H. (1982) Similarity of secretory protein-I from parathyroid gland to chromogranin A from adrenal medulla. Proc. natn. Acad. Sci. USA 79, 6056-60.

COHN, D. V., ELTING, J. J., FRICK, M. \& ELDE, R. (1984) Selective localization of the parathyroid secretory protein-I/adrenal medulla chromogranin A protein family in a wide variety of endocrine cells of the rat. Endocrinology 114, 1963-74.

DUDEK, R. W., VARNDELL, I. M. \& POLAK, I. M. (1984) Combined quick-freeze and freeze-drying 
techniques for improved electron immunocytochemistry. In Immunolabelling for Electron Microscopy (edited by POLAK, J. M. and VARND ELL, I. M.), pp. 235-48. Amsterdam: Elsevier Science Publishers.

FACER, P., BISHOP, A. E., LLOYD, R. V., WILSON, B. S., HENNESSY, R. J. \& POLAK, J. M. (1985) Chromogranin: a newly recognised marker for endocrine cells of the human gastrointestinal tract. Gastroenterology (in press)

FALKenSAMMER, G., FISCHER-COLBRIE, R., RICHTER, K. \& WINKLER, H. (1985) Cell-free and cellular synthesis of chromogranin A and B of bovine adrenal medulla. Neuroscience 14, 735-46.

FISCHER-COlbrie, R., SCHACHINGER, M. ZANGERLE, R. \& WINKLER, H. (1982) Dopamine- $\beta$ hydroxylase and other glycoproteins from the soluble content and the membranes of adrenal chromaffin granules: isolation and carbohydrate analysis. J. Neurocherm. 38, 725-32.

GAlfre, G., HOWE, S. C., Milstein, C., BUTCHeR, G. W. \& HOWARD, J. C. (1977) Antibodies to major histocompatibility antigens produced by hybrid cells. Nature, Lond. 266, 550-2.

GRIMELIUS, L. (1968) The argyrophil reaction in islet cells of adult human pancreas studied with a new silver nitrate procedure. Acta soc. medic. upsaliensis 73, $271-94$.

GRIMELIUS, L \& WILANDER, E. (1984) Silver impregnation and other non-immunocytochemical staining methods. In Current Trends in Tumour Pathology (edited by WRIGHT, N. A. and AZZOPARDI, J.), Vol. 1, Endocrine Tumours - the Pathobiology of Regulatory Peptide-producing Tumours (edited by POLAK, J. M. and BLOOM, S. R.), pp. 95-115. Edinburgh: Churchill Livingstone.

HAMPERL, H. (1927) Uber die 'gelben' (chromaffinen) Zellen im gesunden und kranken magendarmschlauch. Virchows Arch path. Anat. 321, 482-507.

HELLE, K. B. (1971) Biochemical studies of the chromaffin granule. II. Properties of membrane-bound and water-soluble forms of chromogranin A and dopamine- $\beta$-hydroxylase activity. Biochim. biophys. Acta 245, 94-104.

HUBER, E., KÖNIG, P., SCHUleR, G., ABERER, W., PlATTNER, H. \& WINKLER, H. (1979) Characterization and topography of the glycoproteins of adrenal chromaffin granules. J. Neurochem. 32, 35-47.

KIANG, W.-L., KRUSIUS, T., FINNE, J., MARGOLIS, R. U. \& MARGOLIS, R. K. (1982) Glycoproteins and proteoglycans of the chromaffin granule matrix. J. biol. Chem. 257, 1651-9.

KIRSHNER, N. (1974) Molecular organisation of the chromaffin vesicles of the adrenal medulla. In Advances in Cytopharmacology, Vol. 2. (edited by CeCARelli, B., Clementi, F. and Meldolesi, J.), pp. 265-72. New York: Raven Press.

KIRSHNER, A. G. \& KIRSHNER, N. (1969) A specific soluble protein from the catecholamine storage vesicles of bovine adrenal medulla. Biochim. biophys. Acta 181, 219-25.

LLOYD, R. V. \& WILSON, B. S. (1983) Specific endocrine tissue marker defined by a monoclonal antibody. Science 222, 628-30.

MASON, D. Y., CORDell, J, L. \& PUlford K. A. F. (1983) Production of monoclonal antibodies for immunocytochemical use. In Techniques in Immunocytochemistry. Vol. 2. (edited by BULLOCK, G. R. and PeTRUSZ, P.), pp. 175-216. London: Academic Press.

O'CONNOR, D. T., BURTON, D. \& DEFTOS, L. J. (1983a) Chromogranin A: Immunohistology reveals its universal occurrence in normal polypeptide hormone producing endocrine glands. Life Sciences $\mathbf{3 3}$, 1657-62.

O'CONNOR, D. T., BURTON, D. \& DEFTOS, L. J. (1983b) Immunoreactive chromogranin A in diverse polypeptide hormone producing human tumors and normal endocrine tissues. J. clin. Endocr. Metab. 57, 1084-6.

O'CONNOR, D. T., FRIGON, R. P. \& SOKOLOFF, R. L. (1984) Human chromogranin A. Purification and characterization from catecholamine storage vesicles of human pheochromocytoma. Hypertension 6 , 2-12.

PHILliPS, J. H. \& APPS, D. K. (1979) Storage and secretion of catecholamines: The adrenal medulla. Physiological and Pharmacological Biochemistry, Int. Reo. Biochem. Vol. 26. (edited by TIPTON, K. F.), pp. 121. Baltimore: University Park Press. 
POLAK, J. M. \& VARNDELL, I. M. (1984) Immunolabelling for Electron Microscopy. Amsterdam: Elsevier Science Publishers.

PORTELA-GOMES, G, M. \& GRIMELIUS, L. (1982) Identification and characterization of enterochromaffin cells with different staining techniques. In Enterochromaffin cells, a qualitative and quantitative study (edited by PORTELA-GOMES, G. M.) PhD thesis, University of Uppsala, Sweden.

SEN, R., SHARP, R. R., DOMINO, L. E. \& DOMINO, E. F. (1979) Composition of the aqueous phase of chromaffin granules. Biochim. biophys. Acta 587, 75-88.

SMITH, A. D. \& WINKLER, H. (1967) A simple method for the isolation of adrenal chromaffin granules on a large scale. Biochem. J. 103,480-2.

TOKUYASU, K. T. (1984) Immuno-cryoultramicrotomy. In Immunolabelling for Electron Microscopy. (edited by POLAK, J. M. and VARNDELL, I. M.), pp. 7I-82. Amsterdam: Elsevier Science Publishers.

VAN EWIJK, W., VAN SOEST, P. L., VERKERK, A. \& IONGKIND, J. F. (1984) Loss of antibody binding to prefixed cells: fixation parameters for immunocytochemistry. Histochem. J. 16, 179-93.

VAN LEEUWEN, F. (1982) Specific immunocytochemical localization of neuropeptides: A Utopian goal? In Techniques in Immunocytochemistry. Vol. 1. (edited by BULLOCK, G. R. and PETRUSZ, P.), pp. 283-95. London: Academic Press.

VAR NDELL, I. M., TAPIA, F. J., PROBERT, L., BUCHAN, A. M. J., GU, J., DEMEY, J., BLOOM, S. R. \& POLAK, J. M. (1982) Immunogold staining procedure for the localisation of regulatory peptides. Peptides 3, $259-72$.

VARNDELL, I. M. \& POLAK, J. M. (1983) The use of immunogold staining procedures in the demonstration of coexistence at the ultrastructural level. In Dale's Principle and Communication between Neurones. (edited by OSBORNE, N. N.), pp. 179-95. Oxford: Pergamon Press.

VARNDELL, I. M. \& POLAK, J. M. (1984) Immunocytochemistry. In Current Trends in Tumour Pathology, Vol. 1. (edited by Wright, N. A. and AZZOPARDI, J.), Endocrine Tumours - the Pathobiology of Regulatory Peptide-producing Tumours, (edited by POLAK, I. M. and BLOOM, S. R.), pp. 116-43. Edinburgh: Churchill Livingstone.

WILSON, B. S. \& LLOYD, R. V.(1984) Detection of chromogranin in neuroendocrine cells with a monoclonal antibody. Am. J. Path 115, 458-68.

WINKLER, H. (1976) The composition of adrenal chromaffin granules: an assessment of controversial results. Neuroscience 1, 65-80.

WINKLER, H. \& CARMICHAEL, S. W. (1982) The chromaffin granule. In The Secretory Granule. (edited by POISNER, A. M. and TRIFARO, J. M.), pp. 3-79. Amsterdam: Elsevier Biomedical Press.

WINKLER, H. \& WESTHEAD, E. W. (1980) The molecular organization of adrenal chromaffin granules. Neuroscience 5, 1803-23. 